\title{
Ultrastructural characteristics of the vitellarium of Brandesia turgida (Brandes, 1888) (Digenea: Pleurogenidae) and an examination of the potential usefulness of such vitelline traits in digenean systematics
}

\author{
L. G. PODDUBNAYA ${ }^{1 *}$, M. BRUŇANSKÁ ${ }^{2}$, T. BRÁZOVÁ ${ }^{2}$, A. E. ZHOKHOV ${ }^{1}$, D. I. GIBSON ${ }^{3}$
}

\begin{abstract}
${ }^{1}$ I. D. Papanin Institute for Biology of Inland Waters, Russian Academy of Sciences, 152742 Borok, Yaroslavl Province, Russia, E-mail: poddubny@ibiw.yaroslavl.ru; ${ }^{2}$ Institute of Parasitology, Slovak Academy of Sciences, 04001 Košice, Hlinkova 3, Slovak Republic; ${ }^{3}$ Department of Life Sciences, Natural History Museum, Cromwell Road, London, SW7 5BD, UK
\end{abstract}

\begin{abstract}
Summary
Transmission electron microscopical observations were made on the vitelline structure of the digenean Brandesia turgida (Brandes, 1888) collected from crypts within the intestinal wall of the frog Pelophylax ridibundus (Pallas, 1771). Ultrastructural details of the vitelline follicles of $B$. turgida include: (a) the presence within the vitellarium of a single type of cell, i.e. vitellocytes at different stages of their development; (b) a narrow region between the vitellocytes filled with the processes of surrounding parenchymal cells; and (c) the occurrence of the junctional complexes between the vitellocytes and the surrounding parenchymal cells at the periphery of the vitelline follicles. It is shown that the vitelline globules and a few lipid droplets are the main inclusions resulting from vitellocyte synthetic activity. The limited amount of nutritive reserves in the vitellocytes can be explained by the nature of the parasite's life-cycle, which is characterized by fully-embryonated intrauterine eggs containing a fully-formed miracidium. Despite the small number of digenean species studied in relation to their vitelline cytoarchitecture, two structural patterns of the vitellarium can be elucidated; these are examined in terms of digenean systematic relationships.
\end{abstract}

Keywords: Brandesia turgida; superfamily Microphalloidea; ultrastructure; vitellarium; digenean families

\section{Introduction}

Brandesia turgida (Brandes, 1888) is an unusual species of digenean which lives in crypts within the intestinal wall of amphibians. It belongs to the family Pleurogenidae Looss, 1899, a group which is included in the large superfamily Microphalloidea Ward, 1901 along with 17 other families (Bray et al., 2008). Ultrastructural investigations of vitellogenesis in the Digenea have previously been undertaken by Tulloch and Shapiro (1957), Björkman and Thorsell (1963), Burton (1963), Koulish (1969), Irwin and Thread- gold (1970), Hanna (1976), Grant et al. (1977), Irwin and Maguire (1979), Erasmus et al. (1982), Fukuda et al. (1983), Holy and Wittrock (1986), Hendow and James (1989), Podvyaznaya (1990, 2003), Sharma and Swarnakar (1992), Chaymardanov and Tanyüksel (1995), Sampour (2008), Świderski et al. (2011), Poddubnaya et al. (2012) and Greani et al. (2012a, b). Although little attention has been paid to the study of the ultrastructural architecture of the digenean vitellarium itself, three aspects of vitelline cytoarchitecture have been suggested as possibly useful phylogenetic indicators for digeneans (Poddubnaya et al., 2012) and for parasitic platyhelminths in general (Poddubnaya et al., 2013). These are: the number of different types of cells within the vitellarium; the presence and type of junctional complexes occurring between these cells; and the isolation of the vitellarium from the surrounding tissues. In relation to this, two different levels of the organization of the vitellarium within the Digenea have been shown. In one group, a single type of cell (vitelline cells at different stages of development) is present (Grant et al., 1977; Holy \& Wittrock, 1986; Podvyaznaya, 1990; Świderski et al., 2011), whereas in another group there are cells of two types (vitelline cells at different stages of development and interstitial cells) within the vitellarium (Irwin \& Threadgold, 1970; Hanna, 1976; Irwin \& Maguire, 1979; Poddubnaya et al., 2012). In relation to this, no members of the family Pleurogenidae have been studied in terms of their vitelline ultrastructure, but, within the superfamily Microphalloidea, species of three other families, i.e. the Microphallidae (see Hendow \& James, 1989; Świderski et al., 2011), the Lecithodendriidae (see Podvyaznaya, 1990) and the Gyrabascidae (see Podvyaznaya, 2003), have been investigated.

In the present study, the ultrastructure of the vitellarium of Brandesia turgida (Plagiorchiida: Pleurogenidae), a parasite which lives in crypts within the intestinal wall of the frog Pelophylax ridibundus (Pallas, 1771) [=Rana ridi- 
bunda], is studied. Our aims were to acquire further information on the vitelline structure of the Digenea and to compare our findings with those known for other digeneans and especially other members of the superfamily Microphalloidea.

\section{Materials and methods}

Adult specimens of Brandesia turgida were obtained from the intestines of the naturally infected frogs Pelophylax ridibundus collected near the Rybinsk Reservoir on the Volga River, Russia. Live digeneans were fixed in $2.5 \%$ glutaraldehyde in $0.1 \mathrm{M}$ sodium cacodylate buffer for 10 days, washed overnight in $0.1 \mathrm{M}$ sodium cacodylate buffer at $\mathrm{pH} 7.4$, postfixed in $1 \% \mathrm{OsO} 4$ in the same buffer for 1 $\mathrm{h}$, dehydrated in a graded series of ethanol and propylene oxide, and embedded in Araldite and Epon epoxy resin. Ultrathin sections were stained with uranyl acetate and lead citrate. Sections were examined using a JEOL-1011 transmission electron microscope operating at $80 \mathrm{kV}$.
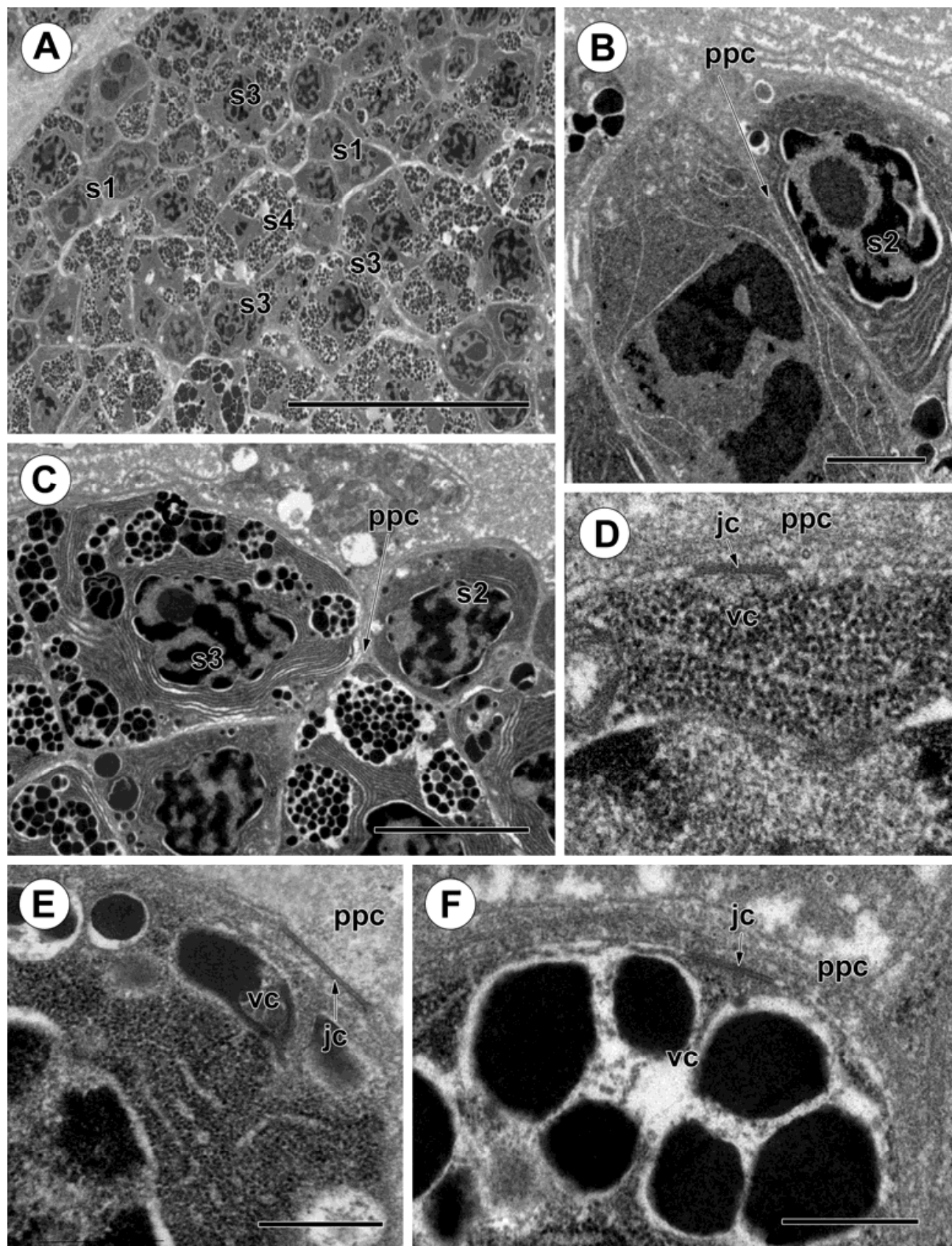

Fig. 1. The disposition of vitellocytes within the vitelline follicles of Brandesia turgida. A. Section of a follicle, showing closely packed vitellocytes at different stages of their development; B, C. Sections of the periphery of a follicle surrounded by the processes of parenchymal cells which penetrate the follicles between the vitellocytes; D - F. Sections through the periphery of a vitelline follicle, showing junctional complexes between the adjacent plasma membranes of peripheral vitellocytes and the processes of the surrounding parenchymal cells.

Abbreviations: jc, junctional complex; ppc, processes of the surrounding parenchymal cells; s1, s2, s3, s4, stages of the vitellocyte maturation; vc, vitellocyte. Scale-bars: A, $20 \mu \mathrm{m}$; B, $2 \mu \mathrm{m}$; C, $5 \mu \mathrm{m}$; D, $0.2 \mu \mathrm{m}$; E, F, $0.5 \mu \mathrm{m}$. 


\section{Results}

Ultrastructural architecture of the vitelline follicles of Brandesia turgida

A small number of large vitelline follicles (Fig. 1A) are situated on both sides of the oral sucker. Each follicle contains only a single type of vitelline cell (vitellocyte) (Fig. 1A). Such vitellocytes situated close together and at various stages of maturation can be observed throughout each follicle (Fig. 1A). Narrow processes of the surrounding parenchymal cells extend deep into the follicle and surround each vitellocyte (Fig. 1B, C). Occasionally, the limiting plasma membranes of the peripheral vitellocytes and those of the processes of the surrounding parenchymal cells run parallel, forming cell junctions resembling slitlike (or tight) junctions referred to as zonulae occludentes (for details of junctional complexes, see Roland et al., 1974) (Fig. $1 \mathrm{D}-\mathrm{F})$.
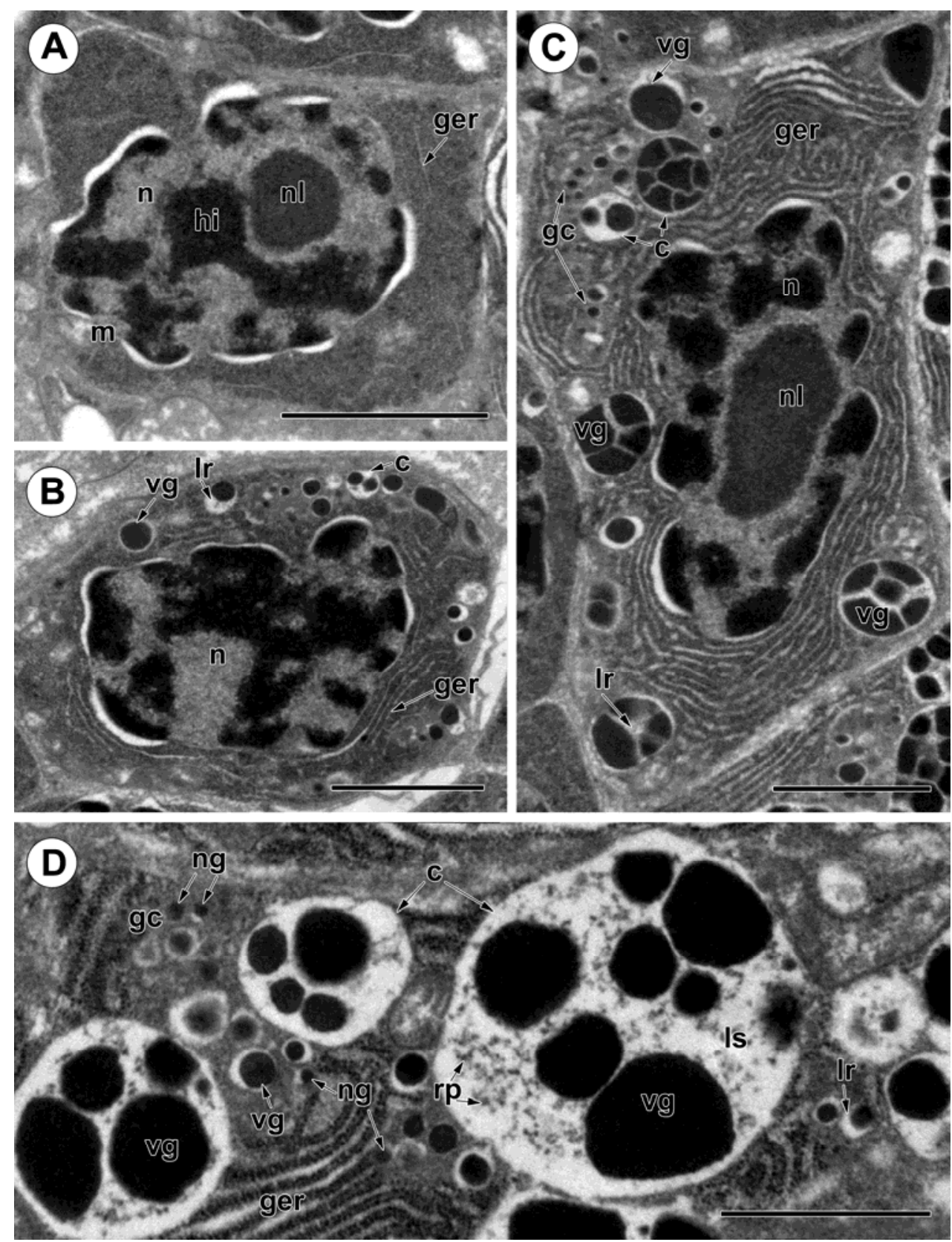

Fig. 2. Stages 1-3 of the vitellocyte maturation of Brandesia turgida. A, Stage 1, note the large nucleus and narrow area of perinuclear cytoplasm with a few mitochondria and few areas of GER; B, Stage 2, showing the appearance of individual vitelline globules; C, Stage 3, showing the early stage of cluster formation with 4-7 sided globules with narrow, electron-lucent spaces between them; D, Vitelline cytoplasm showing a later stage of cluster of formation, with the appearance of larger clusters of loosely packed vitelline globules and the presence of dense ribosome-like particles within the electron-lucent space; note nascent globules within the Golgi vesicles. Abbreviations: c, cluster of united vitelline globules;

gc, Golgi complex; ger, granular endoplasmic reticulum; hi, heterochromatic islands; lr, electron-lucent rim around individual vitelline globule

ls, electron-lucent space within vitelline clusters; $\mathrm{m}$, mitochondrion; n, nucleus; ng, nascent globule; nl, nucleolus; rp, ribosome-like particles; vg, vitelline globule. Scale-bars: A-C, $2 \mu \mathrm{m} ; \mathrm{D}, 1 \mu \mathrm{m}$. 


\section{Early vitellocyte development (stage 1)}

These cells are characterized by a large nucleus with large heterochromatic islands, some of which are attached to the inner nuclear membrane (Fig. 2A). There is a prominent, spherical nucleolus. A narrow region of perinuclear cytoplasm is filled with free ribosomes, a few mitochondria and occasional profiles of granular endoplasmic reticulum (GER) (Fig. 2A).
The appearance of vitelline globules in the vitellocyte (stage 2)

This stage of vitellocyte maturation is distinguished by the presence of numerous profiles of GER, which occupy the greater part of the cytoplasm of these cells (Fig. 2B). Vitelline globules first condense in tiny microvesicles of the Golgi complexes and appear as small, spherical, electrondense bodies of $0.03-0.1 \mu \mathrm{m}$ in diameter (Fig. 2B, D).
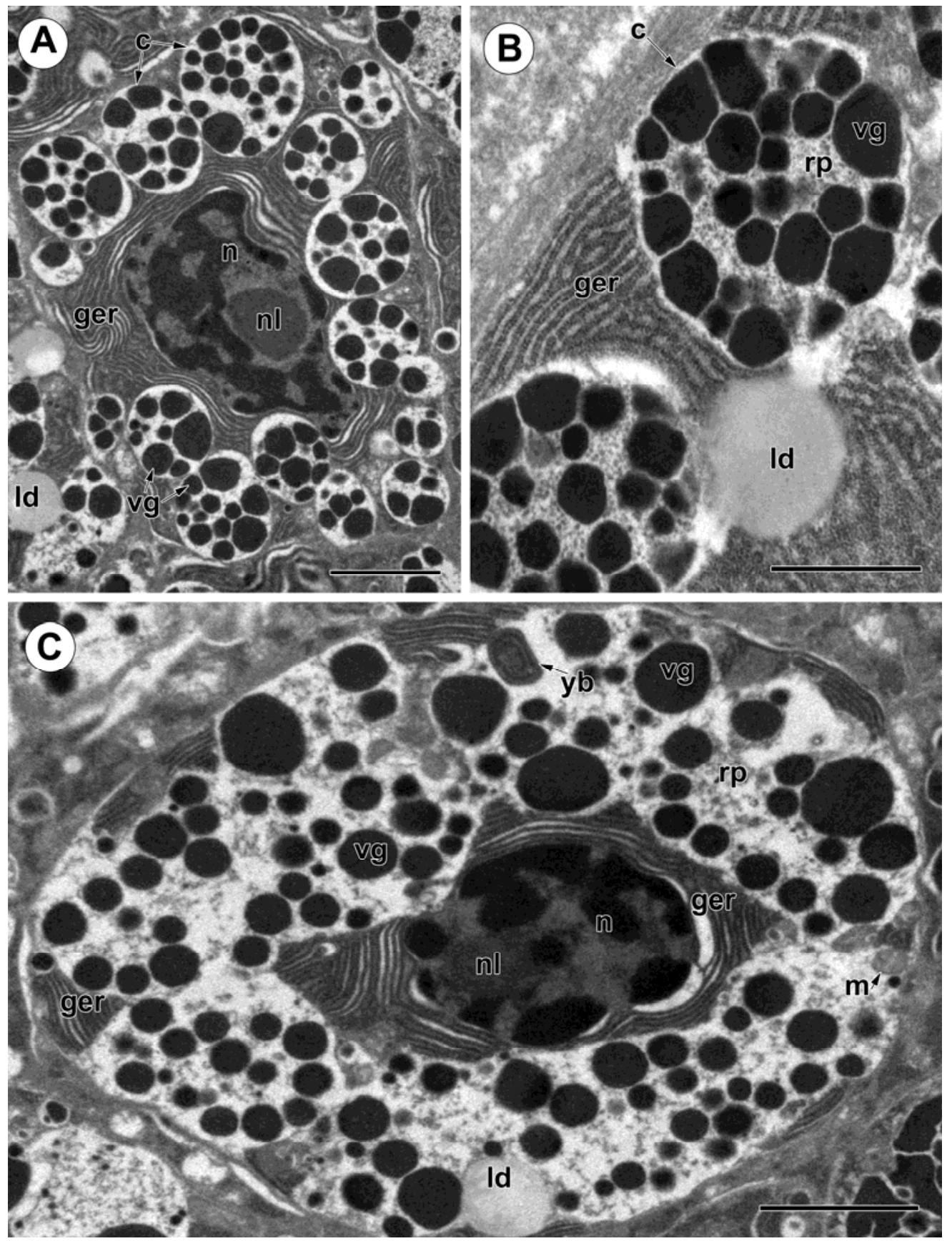

Fig. 3. Advanced stage (stage 4) of developing and mature vitellocytes of Brandesia turgida. A, Advanced stage of developing vitellocyte filled with numerous large vitelline clusters; B, Cytoplasmic area of developing vitellocytes showing large clusters with globules of different sizes, ribosome-like particles and individual lipid droplets; $\mathrm{C}$, Mature vitellocytes; note the central position of the nucleus, which is surrounded by a narrow area of GER and, also in the cytoplasm, are small peripheral islands of GER, free, loosely packed vitelline granules and individual lipid droplets, but no formed vitelline clusters. Abbreviations: c, cluster of united vitelline globules; ger, granular endoplasmic reticulum; ld, lipid

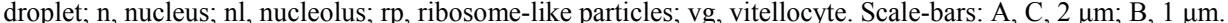


Subsequently, the globules increase in electron density and size, and when $0.2-0.5 \mu \mathrm{m}$ in diameter acquire an electron-lucent rim (Figs. 2B, D). In rare cases, the presence of two granules embedded in an electron-lucent sphere, forming a so-called cluster, can occur (Fig. 2B). Such early clusters are $\sim 0.4 \mu \mathrm{m}$ in diameter.

Later vitellocyte development (stage 3)

An increased cytoplasmic volume of the developing vitellocytes is full of GER and Golgi complexes (Fig. 2C).
Most vitelline globules accumulate in clusters, which can contain up to seven granules; these are angular in appearance as a result of their compression (Fig. 2C). Between the heterogeneous electron-dense globules within the clusters, there is a narrow, electron-lucent space (Fig. 2C). The diameter of these clusters is $\sim 1 \mu \mathrm{m}$. Subsequently, the clusters coalesce, forming larger structures $<2.5 \mu \mathrm{m}$ in diameter and containing up to 25 round, loosely packed globules (Figs. 2D, 3A, B). Within such large clusters, the globules are variable in size, $0.15-1 \mu \mathrm{m}$ in diameter, and
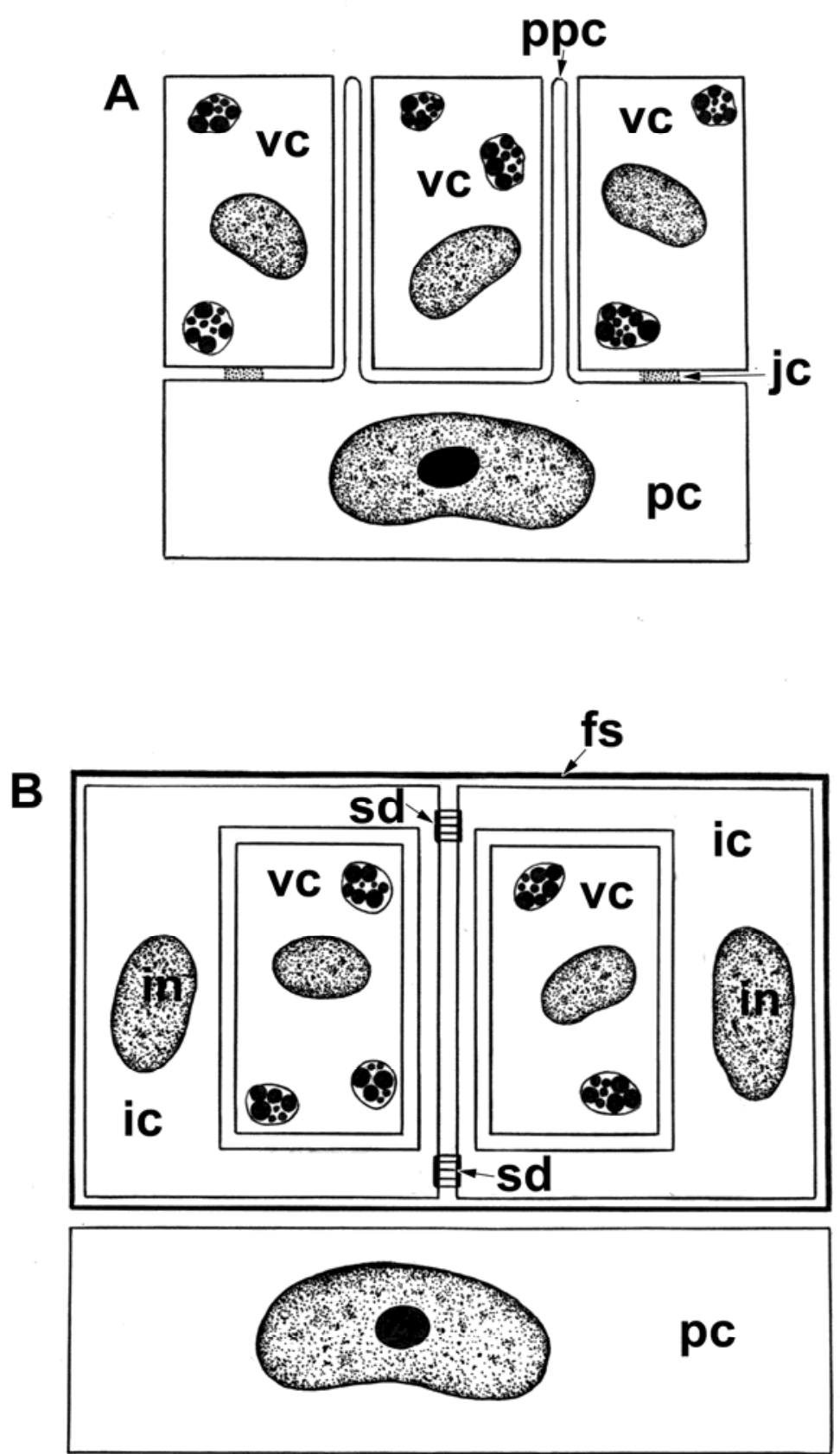

Fig. 4. Diagrammatic representation of two variations in the ultrastructure of the vitellarium of digeneans. A, The first arrangement, in which vitellocytes within the vitelline follicle are not isolated from the surrounding tissue and may or may not have intercellular junctions between these cells and the processes of surrounding parenchymal cells; B, The second arrangement, in which the vitellocytes within the follicle are isolated from the surrounding tissue by a fibrous sheath, there are two types of cells within vitellarium (vitellocytes and interstitial cells) and intercellular junctions occur between the interstitial cells. Abbreviations: fs, fibrous sheath; ic, interstitial cell cytoplasm; in, interstitial cell nucleus;

jc, junctional complex; pc, parenchymal cell; ppc, processes of the surrounding parenchymal cells; sd, septate desmosome; vc, vitellocyte. 
dense ribosomal-like particles can be seen between them (Figs. 2D, 3A, B). At this stage of vitellocyte development, lipid droplets $(\sim 1 \mu \mathrm{m}$ in diameter) of moderately electrondensity can be observed (Fig. 3A, B). The nucleus of the developing vitelline cells contains large islands of heterochromatin and a prominent, spherical nucleolus (Fig. 3A).

\section{Mature vitellocytes (stage 4)}

The nucleus of mature vitellocytes occupies a central position within the cell, around which there are small areas of GER (Fig. 3C). Similar areas of GER are also localized close to the cell plasma membrane, adjacent to which individual yolk bodies, lipid droplets and a few mitochondria can be observed (Fig. 3C). Most of the cytoplasm contains numerous isolated vitelline globules, which are not organized into clusters but loosely packed, along with dense ribosome-like particles and individual lipid droplets (Fig. 3C). No glycogen is apparent.

\section{Discussion}

Characteristics of the vitelline structure of members of the superfamily Microphalloidea

Based on the present study of the vitellarium of the pleurogenid digenean Brandesia turgida, characteristics of the vitelline ultrastructure of this species have been revealed: (a) the presence within the vitellarium of a single type of cell, i.e. vitellocytes at different stages of their development; (b) a narrow region between the vitellocytes filled with the processes of surrounding parenchymal cells; and (c) junctional complexes between the vitellocytes and the surrounding parenchymal cells at the periphery of the vitelline follicles (Fig. 4 A). It should be noted that the vitellarium of two microphallids, Maritrema linguilla (see Hendow \& James, 1989) and M. feliuli (see Swiderski et al., 2011), and the lecithodendriid Paralecithodendrium ascidia (see Podvyaznaya, 1990, as Prosthdendrium ascidia) has a similar vitelline cytoarchitecture to that of $B$. turgida. Although, with the exception of B. turgida, there was in these species no report of the presence of junctional complexes between the vitellocytes and the surrounding parenchymal cells. Nevertheless, in Gyrabascus amphoraeformis, a member of another microphalloid family, the Gyrabascidae, Podvyaznaya (2003, as Allassogonoporus amphoraeformis) indicated the presence of one type of cell within vitellarium and a boundary layer between the vitellarium and surrounding parenchymal cells. However, in our view Podvyaznaya's figure 6G, showing a vitelline follicle of $G$. amphoraeformis, does not support her opinion regarding the presence of a fibrous sheath around the follicles of this species. Thus, it appears that species of the microphalloid families so far studied, the Microphallidae, Lecithodendriidae, Pleurogenidae and, in our view, Gyrabascidae, have the same basic vitelline structure. According to Bray et al. (2008), this superfamily is not defined on morphological grounds, as it is difficult to detect morphological synapomorphies. As the inclusion of many of the 18 families of this superfamily is based on molecular findings and the group contains a wide morphological variation, it has not been possible to develop an entirely reliable key. Judging from our comparative analysis, it is suggested that the vitelline pattern, characterized by the presence of one type of cell within vitellarium and without any isolation from the surrounding parenchymal cells, is a specialized vitelline structure present in those families of the Microphalloidea investigated so far.

The present study of $B$. turgida has shown that vitelline globules and a few lipid droplets are the main inclusions resulting from the synthetic activity of the vitellocytes. The same types of inclusion have been indicated for vitellocytes of members of the other microphalloid families studied (Hendow \& James, 1989; Podvyaznaya, 1990, 2003; Swiderski et al., 2011). Moreover, for these species, the limited amount of nutritive reserves (only a few lipid droplets and little or no glycogen) in their vitellocytes can be explained by the nature of their life-cycle. These species are characterized by fully-embryonated intrauterine eggs containing a fully-formed miracidium. Consequently, the developing larvae obtain their nutrients directly from the parent worm, probably by the diffusion of the glucose through the shell during the egg's passage down the uterus (Hendow \& James, 1989). According to Ginetsinskaya (1968), there is a direct correlation between the degree of development of the vitellarium and uterus in the Digenea which depends on the pattern of development of the miracidium. Worms with fully-embryonated intrauterine eggs possess a long uterus, in contrast to those where the development of the larva occurs after eggs-laying, which have a short uterus.

It is interesting to note that mature vitellocytes of $B$. turgida are filled with loosely packed vitelline globules which are free within the cytoplasm and lack any organization into clusters. The same situation has been described for a microphallid by Hendow and James (1989) and, judging from published micrographs, also occurs in another microphallid (Swiderski et al., 2011) and a lecithodendriid (Podvyaz-naya, 1990). According to Hendow and James (1989), this may be a general feature of the Microphallidae (and thus, in view of the above, possibly of the Microphalloidea) in which the vitellocytes rupture prior to eggshell production, in contrast to most other digeneans species, where entire nucleate vitellocytes are enclosed within the eggs.

In addition to the microphalloids mentioned above, a similar vitelline cytoarchitecture has been found in a small number but wide range of digeneans, i.e. the diplostomid Pharyngostomoides procyonis by Grant et al. (1977), the derogenid Halipegus eccentricus by Holy and Wittrock (1986) and the dicrocoeliid Dicrocoelium dendriticum by Chaymardanov and Tanyüksel (1995). In a paper on a comparative study of the vitelline cells in four species of the schistosomatid genus Schistosoma, Erasmus et al. (1982) gave no indication of the ultrastructural architecture of the vitellarium, but, on the basis of their figure ' $A$ ' in plate 1 , we could detect no fibrous sheath around follicles and only one type of cell within the vitellocytes. 
Characteristics of another type of vitelline structure within the Digenea

In the gorgoderids Gorgoderina vitelliloba (see Irwin \& Maguire, 1979) and Phyllodistomum angulatum (see Poddubnaya et al., 2012) a different type of basic structure of the vitellarium is found. This includes the presence of: (1) two types of cells within the vitelline masses (vitellocytes and interstitial cells, the latter with the same cytomorpho$\operatorname{logy})$; (2) intercellular septate junctions between the interstitial cells; and (3) a fibrous sheath surrounding the vitelline masses (Fig. 4 B). The same vitelline cytoarchitecture as occurs in the gorgoderids has also been found in the azygiid Azygia lucii by Poddubnaya et al. (2012), in the fasciolid Fasciola hepatica by Irwin and Threadgold (1970) and Hanna (1976), in the paramphistomid Orthocoelium scoliocoelium by Sharma and Swarnakar (1992) and in the haploporid Haploporus lateralis by Sampour (2008).

Finally, despite the small number of digenean species studied in relation to their vitelline cytoarchitecture, specific structural patterns of the vitellarium can be observed in certain digenean families or even superfamilies. It is shown above that there are two known variations in the vitelline ultrastructure within the Digenea (Fig. 4). The question remains, is this difference of systematic/ phylogenetic significance or a feature of their biology? According to most authorities, e.g. La Rue (1957), Cable (1974), Gibson \& Bray (1994), Galaktionov and Dobrovolskij (2003) and Olson et al. (2003), the digeneans can be split into a small number (usually two) of phylogenetic branches (usually Orders). These groups are generally referred to as the Strigeida (or Diplostomida) and Plagiorchiida (or Echinostomida + Plagiorchiida). Evidence so far indicates that both types of vitelline structure occur on either side of this divide, although, in the case of the second arrangement, this depends upon the classification followed. However, a greater range of digenean families will need to be investigated before any definitive answer is possible.

\section{Acknowledgments}

The authors would like to thank the staff of the Centre of Electron Microscopy, I.D. Papanin Institute for the Biology of Inland Waters, Russian Academy of Sciences, Borok, Russia, for their help. The work was within the framework of a project of the Parasitological Research and Training Centre of the SAS (Code ITMS: 26110230045) based on the support of the Operational Programme "Education" funded from the European Regional Development Fund. The present study was supported by the Russian Foundation for Fundamental Research Project no. 12-04-00149-a to LP and the Grant Agency of the Slovak Republic VEGA Project no. 2/0047/11 to MB.

\section{References}

BRAY, R. A. (2008): Superfamily Microphalloidea Ward,
1901. In: Bray, R. A., Gibson, D. I., Jones, A. (Eds) Key to the Trematoda. Volume 3. London, UK: CABI Publishing and the Nature History Museum, pp.447 - 450.

BJÖRKMAN, J., THORSELL, W. (1963): On the fine morphology of the formation of egg shell globules in the vitelline gland of the liver fluke, Fasciola hepatica L. Exp. Cell. Res., 32, 153 - 156. DOI: 10.1016/00144827(63)90077-6

BurTON, P. R. (1963): A histochemical study of vitelline cells, egg capsules, and Mehlis'gland in the frog lungfluke, Haematoloechus medioplexus. J. Exp. Zool., 154, $247-257$

CABLE, R. M. (1974): Phylogeny and taxonomy of trematodes with reference to marine species, In: VERNBERG, W. E. (Ed) Symbiosis in the Sea, Columbia, South Carolina, U.S.A.: University of South Carolina Press. pp. 173 - 193

Chaymardanov, J. K., TANYÜKSEL, M. (1995) Morphological and histochemical observations on the vitelline cells of adult Dicrocoelium dendriticum. Turk. J. Zool., $19,323-329$

ERASmus, D. A., PoOPIEl, I., SHaW, R. (1982): A comparative study of the vitelline cell in Schistosoma mansoni, S. haematobium, S. japonicum and S. mattheei. Parasito$\log y, 84,283-287$

FUKUDA, K., HAMAJIMA, F., ICHIKI, Y. (1983): Ultrastructural study on the vitelline cell of the lung fluke Paragonimus ohirai. Jap. J. Parasitol., 32, 439 - 449

Galaktionov, K. V., DobrovolskiJ, A. A. (2003): The biology and evolution of trematodes. Kluwer Academic Publishers, Boston, Dordrecht, London, $592 \mathrm{pp}$.

GIBSON, D. I., BRAY, R. A. (1994): The evolutionary explanation and host-parasite relationships of the Digenea. Int. J. Parasitol., 24, 1213 - 1226. DOI: 10.1016/00207519(94)90192-9

GINETSINSKAYA, T. A. (1968): [Trematodes, their life cycles, biology and evolution]. Leningrad, USSR: Nauka. (Translated, 1988, Amerind Publ. Co. Pvt. Ltd., New Delhi. 559 pp.

GRANT, W. C., HARKEMA, R., Muse, K. E. (1977): Ultrastructure of Pharyngostomoides procyonis Harkema 1942 (Diplostomatidae). II. The female reproductive system. $J$. Parasitol., 63, $1019-1030$

Greani, S., Quilichini, Y., FoATa, J., Marchand, B. (2012a): Ultrastructural study of vitellogenesis of Aphallus tubarium (Rudolphi, 1819) Poche, 1926 (Digenea, Cryptogonimidae), an intestinal parasite of Dentex dentex (Pisces: Teleostei). J. Parasitol., 98, 938 - 946. DOI: 10.1645/GE-3123.1

Greani, S., Quilichini, Y., FoATA, J., Swiderski, Z., MARCHAND, B. (2012b): Ultrastructural study of vitellogenesis and oogenesis of Metadena depressa (Stossich, 1883) Linton, 1910 (Digenea, Cryptogonimidae), intestinal parasite of Dentex dentex (Pisces, Teleostei). C. R. Biol., $335,657-667$.

HANNA, R. E. B. (1976): Fasciola hepatica: a light and electron autoradiographic study of shell protein and glycogen synthesis by vitelline follicles in tissue slices. Exp. Parasitol., 39, 18 - 28. DOI: 10.1016/0014-4894(76)90005-9 
Hendow, H. T., JAMES, B. L. (1989): Ultrastructure of vitellarium, vitellogenesis and associated ducts in Maritrema linguilla (Digenea: Microphallidae). Int. J. Parasitol., 19, 489 - 497. DOI: 0020-7519/98S0.00+0.00

Holy, J. M., WitTROCK, D. D. (1986): Ultrastructure of the female reproductive organs (ovary, vitellaria, and Mehlis' gland) of Halipegus eccentricus (Trematoda: Derogenidae). Can. J. Zool., 64, 2203-2213

IRWIN, S. W., MAGUIRE, J. G. (1979): Ultrastructure of the vitelline follicles of Gorgoderina vitelliloba (Trematoda: Gorgoderidae). Int. J. Parasitol., 9, 47 - 53. DOI: 10.1016/0020-7519(79)90065-1

IRWIN, S. W. B., ThreAdGold, L. T. (1970): Electronmicroscope studies on Fasciola hepatica. VIII. The development of the vitelline cells. Exp. Parasitol., 28, $399-$ 411. DOI: 10.1016/0014-4894 (70)90108-6

Koulish, S. (1969): Observations on the origin of two substances produced by the vitellaria in Gorgoderina attenuate. J. Morphol., 127, 431 - 438

LA RUE, G. R. (1957): The classification of digenetic Trematoda: a review and a new system. Exp. Parasitol., 6, $306-349$

Olson, P. D., CribB, T. H., TKACH, V. V., Bray, R. A., LiTTLEWOOD, D. T. J. (2003): Phylogeny and classification of the Digenea (Platyhelminthes: Trematoda). Int. J. Parasitol., 33, 733 - 755. DOI: 10.1016/S0020-7519(03)00049-3 PODVYAZNAYA, I. M. (1990): The morphology and ultrastructure of the female reproductive system of Prosthodendrium ascidia (Trematoda, Lecithodendriidae). In: MAMKAEV, YU.V., IOFFE, B. I. (Eds) Parasitic and free-living Plathelminthes: faunistics and morphology. Tr. Zool. Inst., Leningrad, 221, 61 - 78 (In Russian)
PodvyAZNAYA, I. M. (2003): Ultrastructural studies of the female reproductive system in a parasite of bats Allassogonoporus amphoraeformis (Digenea: Allassogonoporidae). Parazitologiya, 37, 387 - 393 (In Russian)

Poddubnaya, L. G., BruŇANSKÁ, M., Świderski, Z., GIBSON, D. I. (2012): Ultrastructure of the vitellarium in the digeneans Phyllodistomum angulatum (Plagiorchiida, Gorgoderidae) and Azygia lucii (Strigeida, Azygiidae). Acta Parasitol., 57, 235 - 246. DOI: 10.2478/s11686-012-0030-9 Poddubnaya, L. G., BruňAnskÁ, M., Świderski, Z., GIBSON, D. I. (2013): Ultrastructure of the vitellarium of Ancyrocephalus paradoxus (Monogenea: Monopisthocotylea), with comments on the nature of the vitellarium in the Monogenea and related platyhelminth groups. Parasitol. Res., 112(3): 1169 - 1177. DOI: 10.1007/s00436-0123248-4

Roland, J-C., SzÖllösI, A., SzÖllösI, D. (1974): Atlas de biologie cellulaire. Paris: Masson et Cie, 120 pp.

SAMPOUR, M. (2008): The study of vitelline gland of Haploporus lateralis (Digenea: Trematoda). Pak. J. Biol. Sci., 11, $113-117$

SHARMA, P. N., SWARNAKER, G. (1992): Ultrastructure and histochemistry of vitelline cells of Orthocoeliums coliocoelium (Trematoda: Digenea). Indian J. Parasitol., 16, $145-154$

Świderski, Z., BaKhoum, A. J. S., Montoliu, I., Felui, C., MiQUEL, J. (2011): Ultrastructural study of vitellogenesis in Maritrema feliui (Digenea, Microphallidae). Parasitol. Res., 109: 1707 - 1714. DOI: 10.1007/s00436-0112444-y

TUllOCH, G. S., SHAPIRO, J. E. (1957): The ultrastructure of the vitelline cells of Haematoloechus. J. Parasitol., 43: $628-632$

ACCEPTED FEBRUARY 4, 2013 